This item was submitted to Loughborough's Research Repository by the author.

Items in Figshare are protected by copyright, with all rights reserved, unless otherwise indicated.

\title{
A Christian anarchist critique of violence: From turning the other cheek to a rejection of the state
}

PLEASE CITE THE PUBLISHED VERSION

\section{PUBLISHER}

(C) Inter-Disciplinary Press

\section{VERSION}

VoR (Version of Record)

\section{PUBLISHER STATEMENT}

This work is made available according to the conditions of the Creative Commons Attribution-NonCommercialNoDerivatives 4.0 International (CC BY-NC-ND 4.0) licence. Full details of this licence are available at: https://creativecommons.org/licenses/by-nc-nd/4.0/

\section{LICENCE}

CC BY-NC-ND 4.0

\section{REPOSITORY RECORD}

Christoyannopoulos, Alexandre J.M.E.. 2019. "A Christian Anarchist Critique of Violence: From Turning the Other Cheek to a Rejection of the State". figshare. https://hdl.handle.net/2134/27365. 


\title{
A Christian Anarchist Critique of Violence: From Turning the Other Cheek to a Rejection of the State
}

\author{
Alexandre Christoyannopoulos
}

\begin{abstract}
Jesus' Sermon on the Mount is seen by many Christians as a moving summary of his message to the community of Christian disciples. For Christian anarchist thinkers like Tolstoy, Ellul, Elliott, and Andrews among others, it also contains Jesus' most poignant statement on violence - his call to turn the other cheek - a statement which, they argue, cannot but ultimately imply a condemnation of the state for its theoretical and practical monopoly over the allegedly legitimate use of violence. This paper offers an overview of this radical political exegesis, thus showing why, for Christian anarchists, the very core of Christianity cannot but imply a form of (non-violent) anarchism.
\end{abstract}

Key Words: Anarchism, Christianity, non-resistance, Sermon on the Mount, violence.

$* * * * *$

\section{Introduction}

'What a fine place this world would be,' a Christian anarchist quipped decades ago, 'if Fundamentalist Protestants tried to exemplify the Sermon on the Mount.' There are, however, divergent interpretations of this Sermon - including perhaps its most famous passage, where Jesus speaks of love and non-resistance. The purpose of this paper is to introduce the anarchist interpretation of Christianity by summarising the scattered comments Christian anarchists have made on this particular passage.

Space restrictions prevent a more detailed analysis of these comments here, but precisely such a detailed analysis, along with that of other passages (including Romans 13 and (render unto Caesar') as well as more in depth exposition and discussion of Christian anarchism more generally, can be found in Christian Anarchism: A Political Commentary on the Gospel. The passage in question here is where Jesus says:

Ye have heard that it hath been said, An eye for an eye, and a tooth for a tooth:

But I say unto you, That ye resist not evil: but whosoever shall smite thee on thy right cheek, turn to him the other also.

And if any man will sue thee at the law, and take away thy coat, let him have thy cloak also. 
And whosoever shall compel thee to go a mile, go with him twain.

Give to him that asketh thee, and from him that would borrow of thee turn not thou away. ${ }^{2}$

\section{Jesus' Three Illustrations}

In the first illustration, both Wink and Elliott suggest, Jesus is depicting a situation which his followers would immediately recognise as humiliating, and which, in that society, would consequently call for an appropriate, equally forceful and humiliating response to uphold one's dignity. The response Jesus recommends, however, goes against these local expectations. For Elliott, Jesus is saying: 'do what your attacker least expects: behave in the opposite way.' ${ }^{3}$ This, Elliott contends, confuses the attacker, who now 'is no longer in control of the process he initiated. He is, in a very real sense, disarmed!" ${ }^{4}$ Similarly, Wink claims that turning the other cheek 'robs the oppressor of the power to humiliate. ${ }^{5}$ Both Elliott and Wink therefore agree that Jesus' surprising response in this first illustration disempowers the attacker and forces him to regard the victim in a different light.

Elliott and Wink develop a similar analysis from the other two responses illustrated by Jesus. The second, they argue, would unmask and put the blame on the social and legal system which brought this about, such that Jesus' recommendation would again be 'a practical, strategic measure for empowering the oppressed. ${ }^{6}$ As to the third, they agree that Jesus' suggested response is 'a way of subverting authority' in that 'the victim is claiming the power to determine for himself the lengths to which he is prepared to go."7 Jesus' illustrations of nonresistance imply a critique of the expectations of his contemporary society and seek to empower the victim through a counter-intuitive response.

\section{A Purposeful Reaction}

At the same time, Jesus' non-resistance is not just a completely inactive, uncaring acceptance of evil, but rather a very specific, strategic response. However, views diverge among Christian anarchists as to exactly what kind of action is allowed and what kind of resistance is forbidden: resistance to certain types of evil, resistance by evil, or any resistance at all. These important disagreements are discussed in detail elsewhere. ${ }^{8}$

Wink, for instance, maintains that a 'proper translation' of the Greek word for 'resist' shows that Jesus was rejecting passive 'flight' or violent 'fight' and recommending 'militant nonviolence.' Ballou, similarly, argues that while Jesus is proscribing violent resistance, evil should still be resisted - just never with evil means. Tolstoy, however, sometimes appears to disagree - but his own position is unclear. At times, he interprets Jesus' recommended reply as not admitting any form of resistance at all, yet sometimes Tolstoy seems to imply that only violent resistance is being forbidden. 
Either way, the point to note here is that although there may be disagreement among Christian anarchists and pacifists about exactly what form of reaction is allowed by these verses, they all (Tolstoy included) insist that the Christian response is a very real and radical (non-violent) reaction - a form of action, a genuine, purposeful, tactical reaction.

\section{Beyond Lex Talionis}

This radical response implies a disapproval of something about his political context, namely: the cycle of violence inherent in lex talionis, the law of retaliation enshrined in the Old Testament.

First, however, it is worth noting that lex talionis is not a licence for unlimited violence. Rather, the idea behind it is justifiable or fair retaliation. Equally important, however, is how this 'fair' and 'just' level of retaliation can be used as a basis for reaching an alternative solution: a 'fair' and 'just' level of compensation. Lex talionis therefore provides the basis for either retributive (punitive) or restorative (compensatory) justice - principles which also permeate contemporary civil and criminal law.

In the above verses, however, Jesus calls for a different approach. Instead of merely avoiding an excessive reaction in line with the limit on violence placed in the Old Testament, Jesus is proposing that his disciples go further. Both the old and new commands are informed by the same intention, but non-resistance to evil goes further than the more rigid law of reciprocity. For Christian anarchists, the reason Jesus does this has to do with the way the law of retaliation can - and usually tends to - spiral out of control and feed a cycle of violence and revenge.

\section{The Cycle of Violence}

Christian anarchists interpret Jesus' instruction as a comment not just on the Old Law, but also on human practice past and present. They generalise Jesus' comments on lex talionis to the broader political question of how to deal with evil and achieve justice in society.

To begin with, they remark that although forceful resistance is almost universally accepted as the justified method for humanity to confront injustice, this method plainly does not work, because it only multiplies evil, creating an unending cycle of vendettas. If the justice of the retaliation is not recognised by its victim, what to one party is only fair retaliation becomes unjustified aggression to the other. In other words, an eye for an eye eventually makes the world go blind. It is hard to overestimate how important this realisation is for all Christian anarchists.

For Christian anarchists, violent means only produce further violence, and they fatally corrupt and destroy even the worthiest of aims. 'When evil means are employed,' Berdyaev insists, 'these ends are never attained: the means take central place, and the ends are either forgotten, or become purely rhetorical. ${ }^{9}$ Countless human goals have been fatally compromised by the violent means which were 
adopted in an attempt to reach them, but which ended up taking centre stage while the original goal became ever more elusive.

Nonetheless, its proponents always try to justify violence (both to others and to themselves) by evoking venerable goals. This is understandable, and proponents of violence usually wholeheartedly believe that the superior ends they long for can be achieved by the violent means they succumb to. Yet the resort to violence is precisely where evil seeps in.

Besides, those who are coerced will only obey while they are weaker than their tyrants. But 'as soon as they grow stronger,' Tolstoy warns, 'embittered by the struggle' and 'everything they have had to suffer,' they, 'in their turn, force their opponents to do what they regard as good and necessary. ${ }^{10}$ Reactionary violence promises counter-reactionary violence.

One of the fundamental problems with violent methods, Christian anarchists argue, is that 'once we consent to use violence ourselves, we have to consent to our adversary's using it, too. ${ }^{, 1}$ Adopting violence as a method to attain one's goals implies the recognition of violence as a legitimate method.

Worse, the use of violence creates justifications for further violence. That is, 'every act of violence can explain and seek to justify itself as a response to an earlier act of violence' - hence the danger inherent in lex talionis. ${ }^{12}$ 'As fire will not put out fire,' Tolstoy therefore believes, 'so evil will not destroy evil., ${ }^{13}$ According to Tolstoy's Jesus, 'by taking revenge, we only teach others to do the same. ${ }^{14}$

Christian anarchists urge every human being to decide where they stand on this. The question of how to respond to evil cannot be avoided. Lex talionis appears to offer a solution, but inherent in it is a tendency for reciprocal violence to spiral out of control. For the vicious cycle of violence to be broken, humanity needs an alternative method for responding to injustice and reaching moral aims.

\section{Overcoming the Cycle of Violence}

Christian anarchists believe Jesus both taught and lived out such an alternative, which is that "evil can be overcome only with good." 15 It is not an easy method, and at first, it can appear counterintuitive in that it implies 'renouncing the marks of victory. ${ }^{16}$ Christian anarchists, however, believe it is 'the only possible way of breaking the chain of violence, of rupturing the circle of fear and hate. ${ }^{17}$

No Christian anarchist pretends that this is painless. Overcoming evil with love requires a willingness to endure violence or evil without doing violence or evil in return, even - in fact, especially - when treated unjustly. Hence it requires forgiveness and sacrifice - including the sacrificing of one's right to restitution or retaliation.

Only such an attitude of love, non-violence and forgiveness makes healing possible. Non-resistance, and its concomitant willingness to suffer unjustly, clears 
the ground for reconciliation; it exposes the destructive violence of the situation and makes a moving plea to overcome it.

Some might object that non-resistance is contrary to human nature in that it goes against the natural instinct of self-preservation. Ballou replies that actually, non-resistance is 'the true method of self-preservation. ${ }^{18}$ For him, resistance divides and actually destroys humanity, whereas non-resistance actually preserves it. Accordingly, non-resistance is the only method which can actually preserve humanity in the long run.

Christian anarchists thus firmly believe in a strict continuity between ends and means, because the means eventually become the ends. Violence leads to violence, resistance to resistance. By the same token, peace, love and forgiveness can only begin with peaceful, loving and forgiving pioneers. The cycle of violence cannot be broken by cathartic or exemplary acts of violence; it can only be overcome by love and non-resistance.

Of course, such non-resistance is not easy. It requires an absolute commitment, and this means a willingness to suffer, even to die, rather than to resist. Thus nonresistance is not cowardly; it requires courage.

Besides, non-resistance is what Jesus undeniably demands. We might think it is utopian or foolish, but for Tolstoy what cannot be denied is that Jesus clearly called his followers not to resist. A faithful follower of Jesus therefore cannot resist, cannot participate in violence.

\section{Anarchist Implications}

The state, however, is founded on violence. To enforce law and order, it demands from its citizens a monopoly over the legitimate use of force. Hence coercion is essential to government, to all governments. The state is founded on the very thing Jesus prohibits.

Christian anarchists reject the differentiation between 'violence,' with its negative connotations, and the state's use of 'force.' Violence founds the state and permeates its day-to-day administration. The state 'cannot maintain itself save by and through violence. ${ }^{19}$ The resulting tragedy is that although the state promises to protect from evil, it itself 'produces evil and extends it. ${ }^{, 2}$

The state is also more visibly violent, hence unchristian, in that it wages war. In doing so, it breaks the older commandment not to kill. Thus 'murder is committed in an organized way and upon a colossal scale by the state. ${ }^{, 21}$

To those who might retort that a distinction should be made between murder and war, Ballou asks rhetorically: "how many does it take to metamorphose wickedness into righteousness?' 22 One person must not kill, several persons must not kill, but states may do it and it's not murder - but how many does it take? Christian anarchists see no valid reason to distinguish between people acting on their own and people doing the same thing through the state. Christian commands apply in both cases. 
As Ballou explains, 'what [a man] does through others he really does himself. ${ }^{23}$ When the state resists evil, its citizens who have consented to it holding power to resist evil are just as responsible for its behaviour as they would be if they had resisted evil themselves.

Hence it is because of their absolute commitment to non-violence that Christian anarchists refuse to endorse the institution and conduct of the state. For them, Jesus' teaching therefore 'involves nothing less than the entire abolition of all compulsory legislation, Law Courts, police, and prisons, as well as all forcible restraint of man by man. ${ }^{24}$ Christianity, that is, involves anarchism.

Hennacy concludes that 'anarchism is the negative side' of 'pacifism and the Sermon on the Mount. ${ }^{25}$ It is because they take Jesus' words in the Sermon on the Mount seriously, and because they consider the state to be, both in theory and practice, in flagrant contravention of these, that Christian anarchists believe anarchism to be an inevitable corollary of Christianity. Christian anarchists move by consistent logical reasoning from Jesus' command not to resist evil, through their assessment of state violence in both theory and practice, to their ultimate rejection of the state.

Therefore, according to Tolstoy, every would-be Christian faces a choice: God or the state, Jesus' teaching and example or state theory and practice. It is impossible to confess both.

\section{Conclusion}

Christian anarchists see the broader Sermon on the Mount as a political document, a manifesto for a Christian anarchist society. They take the political implications of Jesus' instructions seriously, especially non-resistance to evil. They insist that Jesus is calling for his disciples to transcend lex talionis, to love and forgive evildoers in order for the cycle of violence which has blighted humanity to be overcome. In that this cannot but require a rejection of state theory and practice, Jesus' words are a call for revolution - a revolution which Jesus further taught and practiced throughout the rest of his life, including even in his acceptance of death by crucifixion.

\section{Notes}

${ }^{1}$ P Maurin, Easy Essays, Rose Hill, Washington, 2003, p. 193.

${ }^{2}$ Matthew 5:38-42.

${ }^{3}$ MC Elliott, Freedom, Justice and Christian Counter-Culture, SCM, London, 1990, p. 176.

${ }^{4}$ ibid.

${ }^{5}$ W Wink, Jesus' Third Way, New Society, Philadelphia, 1987, p. 16.

${ }^{6}$ ibid., p. 19.

${ }^{7}$ Elliott, Freedom, Justice and Christian Counter-Culture, p. 177. 
${ }^{8}$ A Christoyannopoulos, Christian Anarchism, Imprint, Exeter, chap. 4.

${ }^{9} \mathrm{~N}$ Berdyaev, The Realm of Spirit and the Realm of Caesar, trans. D Lowrie, Victor Gollancz, London, 1952, p. 88.

${ }^{10}$ L Tolstoy, 'The Law of Love and the Law of Violence', A Confession and Other Religious Writings, Penguin, London, 1987, p. 163.

${ }^{11}$ J Ellul, Violence, trans. C Gaul Kings, SCM, London, 1970, p. 99.

${ }^{12}$ A Goddard, Living the Word, Resisting the World, Paternoster, Milton Keynes, 2002 , p. 168.

${ }^{13}$ L Tolstoy, What I Believe, CW Daniel, London, 1902, p. 49.

${ }^{14}$ L Tolstoy, 'The Gospel in Brief', A Confession and the Gospel in Brief, Oxford UP, London, 1933, p. 269.

15 A Ballou, 'Christian Non-Resistance', Viewed on 12 February 2007, http:// www.adinballou.org/cnr.htm.

${ }^{16}$ Ellul, Violence, p. 173.

${ }^{17}$ ibid.

${ }^{18}$ Ballou, 'Christian Non-Resistance'.

${ }^{19}$ Ellul, Violence, p. 84.

${ }^{20}$ Berdyaev, The Realm of the Spirit and the Realm of Caesar, p. 83.

${ }^{21}$ N Berdyaev, 'Personality, Religion, and Existential Anarchism', L Krimerman \& L Perry (eds), Patterns of Anarchy, Anchor, Garden City, 1966, p. 159.

${ }^{22}$ A Ballou, The Kingdom of God and Peace Essays, Rupa, New Delhi, 2001, p. 13.

${ }^{23}$ Ibid., p. 16.

${ }^{24}$ A Maude, The Life of Tolstóy, Oxford UP, London, 1930, p. 36.

${ }^{25}$ A Hennacy, The Book of Ammon, Fortkamp, Baltimore, 1994, p. 99.

\section{Bibliography}

Ballou, A., The Kingdom of God and Peace Essays. Rupa, New Delhi, 2001.

Ballou, A., 'Christian Non-Resistance', Viewed on 12 February 2007, http://www. adinballou.org/cnr.htm.

Berdyaev, N., 'Personality, Religion, and Existential Anarchism'. Patterns of Anarchy. Krimerman, L. \& Perry, L. (eds), Anchor, Garden City, 1966.

Berdyaev, N., The Realm of Spirit and the Realm of Caesar. Victor Gollancz, London, 1952.

Christoyannopoulos, A., Christian Anarchism. Imprint, Exeter. 
Elliott, M.C., Freedom, Justice and Christian Counter-Culture. SCM, London, 1990, p. 176.

Ellul, J., Violence. trans. Gaul Kings, C., SCM, London, 1970.

Goddard, A., Living the Word, Resisting the World. Paternoster, Milton Keynes, 2002.

Hennacy, A., The Book of Ammon. Fortkamp, Baltimore, 1994, p. 99.

Maude, A., The Life of Tolstóy. Oxford UP, London, 1930.

Maurin, P., Easy Essays. Rose Hill, Washington, 2003, p. 193.

Tolstoy, L., 'The Law of Love and the Law of Violence'. A Confession and Other Religious Writings. Penguin, London, 1987.

Tolstoy, L., What I Believe. CW Daniel, London, 1902.

Tolstoy, L., 'The Gospel in Brief'. A Confession and the Gospel in Brief. Oxford UP, London, 1933.

Wink, W., Jesus' Third Way. New Society, Philadelphia, 1987, p. 16.

Alexandre Christoyannopoulos is a Lecturer in Politics and History at Loughborough University. Further biographical details and a list of his publications are available via http://www.christoyannopoulos.com. 